\title{
IMPLEMENTASI STRATEGI POSE UNTUK MEMBERDAYAKAN CRITICAL THINKING MAHASISWA STKIP PGRI BLITAR
}

\author{
Suryanti $^{1}$, Cicik Pramesti ${ }^{2}$ \\ ${ }^{1,2)}$ Program Studi Pendidikan Matematika, STKIP PGRI Blitar \\ 1)yantinadhy@yahoo.co.id, ${ }^{2)}$ cicik_stkipblt@yahoo.com
}

\begin{abstract}
Background of the problem is that students are unable to predict and organize structures in Aljabar Structure I subject which is used as a tool to show a statement. The purpose of this research is to describe the implementation of POSE strategy (Predict, Organize, Summarize and Evaluate) which can empower critical thinking to students of mathematic education program of STKIP PGRI Blitar in Aljabar Structure I subject. The research uses qualitative approach with research design of Eliot model class action. The result based on the final test in the classical cycle $89,5 \%$ of the 19 students who take the test are in the category of critical potency good or excellent. The average percentage of final observation for lecturer and students activities in every meeting is catagorized good and excellent. The result of critical thinking activity sheet (LACT) in every meeting is in category good critical potency or critical potency. The result conclude that the implementation of POSE strategy which can empower critical thinking to students of mathematic education programme in subject of Structure Aljabar I.
\end{abstract}

Keywords: strategi POSE, memberdayakan, critical thinking

\section{PENDAHULUAN}

Kegiatan perkuliahan pada program studi pendidikan matematika tidak hanya dipandang sebagai proses mengajar saja, melainkan juga mempunyai peran penting dalam memberi contoh langsung pembelajaran yang ada di kelas bagi mahasiswa calon guru. "Kualitas pembelajaran dapat diartikan sebagai intensitas keterkaitan sistemik dan sinergis dosen, mahasiswa kurikulum dan bahan belajar, media, fasilitas dan sistem pembelajaran dalam menghasilkan proses dan hasil belajar yang optimal sesuai dengan tuntutan kurikuler." (Tim, 2007:7).

Kualitas pembelajaran yang baik merupakan idaman bagi insan pendidikan. Pengembangan strategi belajar yang melibatkan berbagai alat, assesmen yang cocok membantu dalam mewujudkan pembelajaran yang berkualitas. Munthe (2009:53) menjelaskan, "desain strategi pembelajaran sangat strategis, karena ia merupakan cara seorang guru atau dosen sebagai ujung tombak perubahan melakukan usaha nyata untuk tercapainya kompetensi. Dengan demikian keberhasilan proses pembelajaran merupakan jaminan kualitas proses perubahan mahasiswa sebagai out-put".

Bekerjasama dalam kelompok, diskusi dan presentasi merupakan metode-metode pembelajaran yang sering digunakan dosen dalam perkuliahan. Upaya tersebut mampu membantu mahasiswa dalam menyampaikan pemikiran mereka tentang tugas yang diberikan oleh dosen pada mata kuliah rumpun pendidikan.

Dari hasil wawancara dengan dosen dan observasi mata kuliah Struktul Aljabar I mahasiswa kurang mampu dalam melakukan prediksi dan mengorganisasi struktur-struktur yang ada untuk digunakan sebagai alat dalam membuktikan suatu pernyataan. Kesulitan mahasiswa dalam memahami pernyataan-pernyataan pada materi Grup disebabkan masalah verbalisme (tidak paham makna). Mahasiswa hafal tentang definisi grup, namun ketika diberi permasalahan baru tidak mampu untuk 
menerapkannya. Seperti pada masalah untuk membuktikan, apakah himpunan bilangan bulat ganjil terhadap operasi perkalian merupakan grup? Mahasiswa sering terjebak dengan menunjukkan inversnya ada, sehingga menghasilkan keputusan yang salah dengan menjawab himpunan bilangan bulat ganjil terhadap operasi perkalian merupakan grup.

Kegiatan-kegiatan belajar yang dilakukan dengan mengembangkan kemampuan mahasiswa dalam mempredikasi (hipotesis), mengorganisasi sampai diperoleh suatu kesimpulan membantu dalam meningkatkan kemampuan berpikirnya. Meningkatnya kemampuan berpikir mahasiswa atau siswa berhubungan dengan motivasi mereka dalam belajar. Motivasi belajar menjadi motor penggerak untuk memberdayakan potensi mahasiswa dalam berpikir kritis.

Critical thinking (berpikir kritis) adalah kegiatan berpikir yang dilakukan dengan mengoperasikan potensi intelektual untuk menganalisis, membuat pertimbangan dan mengambil keputusan secara tepat dan melaksanakannya secara benar (Untari dan Kamdi, 2007:26). Spliter (dalam Komalasari, 2010:266) mengemukakan bahwa keterampilan berpikir kritis adalah keterampilan bernalar dan berpikir reflektif yang difokuskan untuk memutuskan hal-hal yang diyakini dan dilakukan.

Pembelajaran POSE merupakan pembelajaran yang terdiri dari strategi Predict, Organize, Summarize dan Evaluate. Strategi POSE merupakan penajaman-penajaman dari reciprocral teaching, strategi POSSE dan metode pembelajaran keterampilan berpikir. Pembelajaran ini lebih ditekankan untuk membantu mahasiswa dalam memahami suatu pernyataan. Pada mata kuliah Struktur Aljabar I, sangat penting bagi mahasiswa untuk mampu memahami pernyataan yang berupa definisi maupun teorema dengan kritis untuk memutuskan kebenarannya.

Strategi POSSE (Predict-Organize-Search-Summarizing-Evaluate) pada The Effect of Applying POSSE on the Students' Reading Comprehension menurut Maha dan Sibarani (2012) pada studi dengan desain eksperimental dihasilkan bahwa aplikasi POSSE pada materi reading comprehension memberikan efek yang signifikan.

Penelitian ini bertujuan untuk mendeskripsikan implementasi strategi POSE yang dapat memberdayakan berpikir kritis mahasiswa prodi Pendidikan Matematika STKIP PGRI Blitar pada matakuliah Struktur Aljabar I.

POSE merupakan desain strategi pembelajaran dengan tahapan Predict, dengan memberikan aktivitas membaca pernyataan untuk melakukan hipotesis, dilanjutkan dengan Organize yaitu mengorganisasi dari struktur-struktur yang pernah diperoleh, tahap berikutnya adalah Summarize disinilah puncak berpikir kritis mahasiswa dalam mengambil keputusan, dan tahap terakhir Evaluate merupakan refleksi dari kegiatan pembelajaran dengan mempresentasikan hasil dari aktivitas pembelajaran dan penguatan dari dosen.

Pada penelitian ini indikator critical thinking adalah mahasiswa dapat memberikan penjelasan sederhana, membangun keterampilan dasar, menguraikan strategi dan taktik, dan membuat penjelasan lebih lanjut.

\section{KAJIAN TEORI}

\section{Konstruktivisme dalam Pembelajaran Matematika}

Pendekatan Konstruktivisme merupakan salah satu pendekatan pembelajaran yang relatif baru dikembangkan pada pendidikan matematika. Pengetahuan harus dikonstruk dan diciptakan melalui aktivitas seperti pengalaman dan merefleksikannya kembali (Krulik, Rudnick, dan Milou, 2003: 6). Hitipieuw (2009:89) menjelaskan bahwa "pendekatan konstruktivistik, menganjurkan pendidik untuk pertama-tama mempelajari pengetahuan dan pengalaman-pengalaman yang telah ada pada siswa berkenaan suatu tugas tertentu".

Accordingly, a mathematical conception is conceived of as an invariant anticipation of an activity-effect realtionship (AER) a learner forms that can be called up to accomplish goals she sets in a situation that she recgnizes. That is, we define conception as a single compound that relates a scheme's second part (activity) and third part (effect), ad denote it AER. Thus, accounts of learners' cognitive fungtioning require including their inferred intentions, not just their observable behaviors (Tzur dan Lambert, 2011:420).

Pembelajaran matematika melalui pendekatan konstruktivisme terangkai dalam konsep (pengetahuan) dapat dikonstruk melalui kegiatan belajar yang dirancang dengan pengalamanpengalaman sehingga menimbulkan suatu akibat (keseimbangan berupa pengetahuan baru). 


\section{Strategi Pembelajaran Berpikir}

Pembelajaran merupakan kegiatan interaksi aktif antara dosen dengan mahasiswa, guru dengan siswa, juga antar mahasiswa atau siswa agar timbul suatu usaha untuk belajar. Keadaan demikian akan muncul apabila dosen/guru/pengajar dapat mendesain suatu strategi pembelajaran yang baik sesuai tujuan pembelajaran yang ingin dicapai. Munthe (2009:53) mengungkapkan, "Desain strategi pembelajaran sangat strategis, karena ia merupakan cara seorang guru atau dosen sebagai ujung tombak perubahan melakukan usaha nyata untuk tercapainya kompetensi. Dengan demikian, keberhasilan proses pembelajaran merupakan jaminan kualitas proses perubahan mahasiswa sebagai out-put".

Perkins (1993) berpendapat tentang pembelajaran berpikir yaitu: Pembelajaran adalah dampak dari berpikir. Retensi, pemahaman, dan penggunaan aktif pengetahuan bisa tercipta hanya dengan pengalaman pembelajaran dimana murid berpikir tentang, dan berpikir dengan, apa yang mereka pelajari (dalam Eggen dan Kauchak, 2012:110).

Eggen dan Kauchak (2012:110-111) juga menekankan tentang pembelajaran dan berpikir saling tergantung. Semakin berkembang penuh keterampilan berpikir siswa, semakin sering mereka belajar. Kemudian semakin sering mereka belajar tentang satu topik, semakin baik mereka berpikir kritis tentang topik itu. Apabila pemahaman mendalam tentang materi (konten) menjadi tujuan, penekanan pada berpikir haruslah demikian.

Kemampuan mahasiswa dalam memahami materi dapat diartikan sebagai berpikir. Pembelajaran yang menekankan pemahaman mahasiswa dilakukan salah satunya dengan kegiatan membaca suatu pernyataan atau topik. Strategi pembelajaran yang berkaitan dengan membaca diantaranya adalah Reciprocal Teaching, POSSE dan keterampilan berpikir.

\section{Reciprocal Teaching}

Untuk memperbaiki pemahaman bacaan, reciprocal teaching merupakan suatu strategi mengajar interaktif yang mempertimbangkan antara pemahaman terhadap teks dan berpartisipasi aktif dalam memahami teks melalui diskusi (Palinscar \& Brown dalam Mercer \& Mercer, 2005:320). Guru dan siswa bekerja bersama dalam memahami bacaan melalui 4 strategi reciprocal teaching, yaitu:

1. Predicting: Siswa diajak untuk mempredikasikan tentang materi yang akan dipelajari melalui perkenalan teks atau pengetahuan sebelumnya terhadap suatu topik. Kegiatan ini dapat membantu siswa untuk mengetahui tujuan membaca.

2. Question generating: Selanjutnya guru memperagakan dan mempraktekan pertanyaan tentang ide pokok suatu bacaan, siswa belajar untuk mengidentifikasi informasi dengan memberikan pertanyaan berdasarkan isi bacaan. Pada kegiatan ini siswa dilatih untuk memahami bacaan dengan membuat pertanyaaan dan menjawab sendiri sebelum dibahas bersama.

3. Summarizing: Guru membimbing siswa dalam menghimpun seluruh informasi pada teks. Kegiatan ini memberi kesempatan pada siswa untuk dimonitor pemahaman bacaannya.

4. Clarifying: Para siswa memberikan perhatian terhadap penjelasan guru mengapa bacaan tersebut sulit untuk dipahami.

Strategi reciprocal teaching membantu siswa dalam memahami bacaan dari suatu topik, diawali dengan mempredikasi isi suatu bacaan, siswa dapat membuat pertanyaan dan jawaban sendiri sampai dapat merangkum tentang bacaan sesuai dengan kepahamannya. Pada strategi ini guru berperan sebagai model dan memberikan latihan yang sesuai, juga memonitor kegiatan siswa selama diskusi, sehingga guru mengetahui kesulitan siswa. Kesulitan-kesulitan selama diskusi diklarifikasi pada akhir pembelajaran.

\section{Strategi POSSE}

Englert and Mariage (Mercer dan Mercer, 2005:320) memperkenalkan POSSE sebagai prosedur reciprocal teaching yang komprehensif untuk memperbaiki daya berpikir siswa terhadap suatu informasi. Tahapan-tahapan strategi POSSE adalah:

1. P-Predict Text ideas based on background knowledge

2. O-Organize the predicted textual ideas and backgound knowledge into a semantic map based on text structure

3. S-Search for the text structure in the expository passage by reading 
4. S-Summarize the main ideas and record the information in a semantic map.

5. E-Evaluate comprehension by comparing the semantic maps, clarify information by asking questions, and predict what information will be in the next text section.

Pada pembelajaran dengan strategi POSSE, para siswa dapat memulai kegiatan dengan dialog atau diskusi dalam kelompok dengan mengungkapkan ide-ide tentang strategi memahami bacaan. Selanjutnya, guru meminta siswa untuk mengkonstruk dan mengorganisasi ide-ide dari strukturstruktur yang ada.

\section{Pembelajaran Keterampilan Berpikir}

Keterampilan berpikir menunjukkan adanya suatu peningkatan pada tahapan-tahapan berpikir, mulai dari berpikir sederhana sampai berpikir kompleks. Pembelajaran saat ini menuntut guru dapat melakukan pengelolaan kelas aktif dalam berpikir agar timbulnya keterampilan berpikir.

Sousa (2012: 295-296) mengungkapkan bahwa praktek harian dan tes di sekolah berfokus pada penyerapan konten pelajaran melalui menghafal, bukan pada proses berpikir untuk menganalisis dan mensintesis masalah. Karenanya, guru perlu bekerja lebih keras saat mengajarkan siswa bagaimana menyusun konten pelajaran sedemikan rupa sehingga mendorong dan mempermudah penggunaan cara berpikir tingkat tinggi. Para guru dapat berperan sebagai model autentik dan berharga, jika mereka mau berpikir kritis dan kreatif untuk meningkatkan praktik-praktik pengajarannya.

Dari ketiga strategi pembelajaran tersebut, sangatlah penting bagi seorang dosen untuk dapat mengembangkan potensi berpikir mahasiswa. Senada dengan Pressley (dalam Desmita, 2012: 137), kunci pendidikan adalah membantu siswa mempelajari serangkaian strategi yang dapat menghasilkan solusi problem.

\section{Critical Thinking (Berpikir Kritis)}

Richard Paul (dalam Fisher, 2007:4) mendefinisikan berpikir kritis adalah mode berpikir mengenai hal, substansi, atau masalah apa saja - dimana si pemikir meningkatkan kualitas pemikirannya dengan menangani secara terampil struktur-struktur yang melekat dalam pemikiran dan menerapkan standar-standar intelektual padanya.

Ennis (dalam Komalasari, 2010:266) membagi indikator keterampilan berpikir kritis menjadi lima kelompok, yaitu: (1) memberikan penjelasan sederhana (elementary clarification), (2) membangun keterampilan dasar (basic support), (3) membuat inferensi (inferring), (4) membuat penjelasan lebih lanjut (advenced clarification), (5) mengatur strategi dan taktik (strategies and tactics).

Menurut Gagne (Desmita, 2012:137) strategi kognitif adalah kemampuan internal yang terorganisasi yang dapat membantu siswa dalam proses belajar, proses berpikir, memecahkan masalah, dan mengambil keputusan.

Setiap mahasiswa mempunyai potensi untuk berpikir kritis. Potensi yang sudah dimiliki seseorang jika tidak dilakukan penajaman, seiring dengan berjalannya waktu akan hilang kerena tidak pernah dilakukan pemanggilan kembali.

\section{Kerangka Implementasi Strategi POSE untuk Memberdayakan Critical Thinking}

Penelitian ini lebih difokuskan pada strategi predict, organize, summarize, dan evaluate (POSE). Keempat strategi tersebut merupakan penajaman dari strategi reciprocal teaching yang menekankan pada interaksi aktif mahasiswa melalui diskusi dengan bertanya dan menjawab, strategi POSSE

memperdalam pemahaman mahasiswa terhadap suatu topik dengan mengkonstruk dan mengorganisasi ide-ide dari struktur-struktur yang ada, dan dipadukan dengan pembelajaran keterampilan berpikir agar memberdayakan berpikir kritis mahasiswa secara aktif melalui media pembelajaran berupa lembar kerja.

Upaya untuk menghasilkan strategi POSE yang dapat mengoptimalkan pembelajaran dilakukan dengan menerapkan berbagai metode pembelajaran yang berpedoman pada indikator berpikir kritis. 
Tabel 1 Kerangka implementasi strategi POSE untuk memberdayakan critical thinking

\begin{tabular}{lll}
\hline \multicolumn{1}{c}{ Kegiatan Dosen } & \multicolumn{1}{c}{ Kegiatan Mahasiswa } \\
\hline - $\begin{array}{l}\text { Meminta mahasiswa untuk membaca } \\
\text { pernyataan tentang Grup }\end{array}$ & - & Membaca pernyataan tentang Grup \\
- $\begin{array}{l}\text { Meminta mahasiswa untuk mengingat } \\
\text { kembali dan menjelaskan informasi dari }\end{array}$ & - & $\begin{array}{l}\text { Menjelaskan informasi dari pernyataan } \\
\text { untuk melakukan hipotesis }\end{array}$ \\
pernyataan untuk melakukan hipotesis & - & Mengorganisasi struktur-struktur yang \\
telah dimiliki dan digunakan dalam \\
- $\begin{array}{l}\text { Membimbing mahasiswa untuk } \\
\text { mengorgansisasi struktur-struktur yang } \\
\text { digunakan dalam menyelesaikan } \\
\text { masalah }\end{array}$ & $\begin{array}{l}\text { menyelesaikan masalah } \\
\text { - } \begin{array}{l}\text { Membimbing mahasiswa dalam } \\
\text { merangkum informasi sebelumnya } \\
\text { dengan peta konsep }\end{array} \\
\text { - Membimbing mahasiswa dalam } \\
\text { mendapatkan kesimpulan }\end{array}$ & $\begin{array}{l}\text { Merangkum dan mengumpulkan } \\
\text { informasi dengan peta konsep }\end{array}$ \\
\hline $\begin{array}{l}\text { Meminta mahasiswa melakukan refleksi } \\
\text { dengan mempresentasikan hasil }\end{array}$ & - & $\begin{array}{l}\text { Membuat kesimpulan sebagai bentuk } \\
\text { keputusan }\end{array}$ \\
\hline
\end{tabular}

\section{METODE PENELITIAN}

Penelitian tindakan kelas ini menggunakan pendekatan kualtitif, dengan rancangan model penelitian tindakan yang dikembangkan oleh John Elliot. Rancangan penelitian tindakan kelas satu siklus terdiri dari 3 pertemuan pembelajaran strategi POSE dan 1 pertemuan tes akhir siklus. Metode penelitia yang diadopsi dari Elliot meliputi langkah-langkah: identifikasi masalah, peninjauan lapangan, merancang instrumen penelitian, implementasi langkah tindakan, memonitor implementasi, peninjauan ulang. Subjek penelitian ini adalah mahasiswa angkatan 2011/2012 offering C yang berjumlah 19 oranng dari prodi Pendidikan Matematika STKIP PGRI Blitar.

Pada penelitian kualitatif ini yang menjadi instrumen utama adalah peneliti sendiri. Kemudian dalam pelaksanaanya peneliti menambahkan instrumen penelitian yang dibutuhkan sebagai alat untuk mengumpulkan data, meliputi: tes akhir siklus, lembar aktivitas critical thinking, dan observasi aktivitas dosen dan mahasiswa.

Analisis data selama pengumpulan data meliputi analisis data tes akhir siklus untuk mengetahui daya kritis mahasiswa setelah dilakukan tindakan pembelajaran dengan strategi POSE. Analisis hasil kerja mahasiswa pada lembar aktivitas critical thinking (LACT) untuk mengetahui daya kritis mahasiswa pada saat berlangsungnya tindakan pembelajaran strategi POSE dengan bantuan LACT. Kemudian data dari hasil observasi aktivitas dosen dan mahasiswa yang telah diamati oleh dua orang observer dirangkum dan direduksi agar diperoleh analsis yang mendalam terhadap hasil observasi.

\section{HASIL DAN PEMBAHASAN \\ Hasil}

Sebelum melakukan PTK, peneliti melakukan identifikasi awal dan peninjauan lapangan dengan melakukan observasi dan diskusi awal dengan dosen prodi Pendidikan Matematika pembina mata kuliah Struktur Aljabar I, diketahui bahwa kegiatan pembelajaran lebih didominasi oleh dosen. Artinya, kegiatan pembelajaran selama ini dilakukan dengan dosen menyampaikan materi dan dilanjutkan dengan pemberian contoh dan tugas-tugas. Diskusi antara mahasiswa kadang-kadang dilakukan dalam bentuk tugas kelompok. Tetapi dari diskusi tersebut belum dapat mengukur kemampuan masing-masing anggota kelompok. Diketahui pula, bahwa penilaian pada mata kuliah Struktur Aljabar I, hanya mengikuti ketentuan sistem penilaian dari kampus dan belum pernah dilakukan penilaian khusus tentang kemampuan berpikir mahasiswa. Rata-rata mahasiswa kurang mampu dalam membaca masalah, menyebabkan kesalahan sering terjadi dalam menyimpulkan bukti pada materi grup dan subgrup. Sedangkan terkait pembelajaran disarankan strategi yang dapat membuat mahasiswa berpikir secara mandiri melalui diskusi yang aktif.

Pada setiap tindakan pembelajaran strategi POSE (yang terdiri dari tahap predict, organize, summarize, dan evaluate) diberikan media berupa lembar aktivitas critical thinking (LACT), yang dimaksudkan untuk memperoleh gambaran mengenai pemahaman (daya kritis) mahasiswa atas materi 
yang disampaikan. LACT dikerjakan secara individu melalui diskusi kelompok. LACT berisi aktivitas-aktivitas strategi POSE dengan memuat indikator berpikir kritis (1) mampu memberikan penjelasan sederhana, mampu membangun keterampil dasar, menguraikan strategi dan taktik, dan mampu membuat penjelasan lebih lanjut.

Selama tindakan berlangsung, tim peneliti memonitor terhadap implementasi langkah tindakan. Monitoring tindakan dilakukan dengan mengamati aktivitas dosen dan mahasiswa melalui lembar observasi yang disesuaikan dengan rencana pelaksanaan pembelajaran (RPP).

Kegiatan peninjauan terhadap hasil tes menunjukkan dari 19 mahasiswa yang mengikuti tes, sebanyak 2 mahasiswa berada pada kategori daya kritis cukup, 15 mahasiswa berada pada ketgori daya kritis baik, dan sebanyak 2 mahasiswa berada pada kategori daya kritis sangat baik. Secara klasikal 17 mahasiswa berada pada kategori daya kritis baik atau sangat baik, dengan persentase daya kritis klasikal 89,5\%. Hal ini berarti secara klasikal daya kritis mahasiswa telah memenuhi kriteria yang ditetapkan terhadap hasil tes yaitu minimal $80 \%$ mahasiswa yang mengikuti tes secara klasikal berada kategori daya kritis baik atau sangat baik.

Peninjauan ulang juga dilakukan pada lembar aktivitas critical thinking (LACT) selama tiga pertemuan. Pada pertemuan yang pertama hasil LACT I menunjukkan dari 19 mahasiswa yang mengikuti pembelajaran POSE, sebanyak 10 mahasiswa berada pada kategori daya kritis baik dan 9 mahasiswa berada pada ketegori daya kritis sangat baik, dengan nilai rata-rata 88,3. Pada pertemuan yang kedua, hasil LACT 2 menunjukkan dari 19 mahasiswa yang mengikuti pembelajaran POSE, sebanyak 10 mahasiswa berada pada kategori daya kritis baik dan 9 mahasiswa berada pada kategori daya kritis sangat baik, dengan nilai rata-rata 87,5. Hasil LACT pertemuan ketiga, diperoleh dari 19 mahasiswa yang mengikuti pembelajaran POSE, sebanyak 15 mahasiswa berada pada kategori daya kritis baik, dan 4 mahasiwa berada pada kategori daya kritis sangat baik, dengan nilai rata-rata 84,2. Hal ini menunjukkan bahwa seluruh mahasiswa yang mengikuti pembelajaran POSE selama 3 pertemuan telah memenuhi kriteria keberhasilan daya kritis terhadap LACT.

Hasil obervasi dosen pada pertemuan pertama menunjukkan persentase rata-rata $85,4 \%$, sedangkan persentase rata-rata hasil observasi mahasiswa yaitu 83,3\%. Pada pertemuan kedua, persentase rata-rata hasil obsevasi dosen yaitu $86,7 \%$ sedangkan persentase rata-rata hasil observasi mahasiswa $81,7 \%$. Hasil observasi dosen pada pertemuan ketiga diperoleh persentase rata-rata 88,3\% sedangkan hasil observasi mahasiswa diperoleh persentase rata-rata $85 \%$.

\section{Pembahasan}

Implementasi strategi POSE pada materi grup matakuliah Struktur Aljabar I untuk memberdayakan berpikir kritis dapat dideskripsikan dengan langkah-langkah sebagai berikut:

Orientasi: Pada tahap orientasi difokuskan pada penyampaian tujuan pembelajaran, strategi pembelajaran dan pembentukan kelompok. Tujuan pembelajaran penting disampaikan kepada mahasiswa agar mereka mempunyai perhatian dan sadar akan tujuan belajar pada awal kegiatan pembelajaran. Pengetahuan awal tentang tujuan membantu mahasiswa untuk mengetahui tujuan pembelajaran yang akan dicapai pada akhir kegiatan. Pada kegiatan ini seluruh mahasiswa memberikan perhatiannya dengan mendengarkan tujuan yang disampaikan dosen. Degeng (2013: 235) menjelaskan “... pemberitahuan tujuan belajar dimaksudkan untuk mengarahkan perilaku belajar siswa. Sasaran akhirnya adalah tercapainya tujuan belajar itu, yaitu siswa mampu menampilkan perilaku seperti yang dispesifikasikan dalam tujuan belajar".

Penyampaian model, startegi, dan metode di awal pembelajaran akan memberikan kepastian bagi mahasiswa bahwa mereka akan melakukan kegiatan pembelajaran dengan cara yang berbeda, yang dapat memberikan gairah atau semangat baru. Bagi mahasiswa pendidikan matematika, model pembelajaran yang berbeda akan membawa dampak positif bagi mereka sebagai calon guru. Penjelasan tentang strategi POSE (predict, observe, summarize dan evaluate) didengarkan dengan seksama oleh seluruh mahasiswa dengan pandangan tertuju pada peneliti.

Dalam strategi pembelajaran POSE untuk memberdayakan berpikir kritis, belajar dalam kelompok akan mempermudah mahasiswa mencapainya. Didalam kelompok belajar orang dewasa akan terakomodasi kemandirian, dialog, dan mempertahankan atau menyampaikan pendapat sebagai bentuk kekritisan mahasiswa.

Strategi pembelajaran POSE didesain untuk mahasiswa bekerja secara mandiri melalui media lembar kerja yang disebut lembar aktivitas critical thinking, yang berisi aktivitas-aktivitas dari setiap 
tahapan pembelajaran POSE yang memberdayakan berpikir kritis. Strategi POSE lebih menekankan seseorang dalam kemampuan membaca dan memahami suatu pernyataan, dengan media LACT mahasiswa dipandu untuk mencapai tujuan pada setiap tahap POSE dengan dipandu pertanyaanpertanyaan yang dapat membuat mereka menunjukkan kemampuan berpikir kritis. Peneliti membagikan LACT pada setiap mahasiswa, artinya walaupun dibentuk kelompok-kelompok belajar, setiap mahasiswa tetap bertanggung jawab terhadap dirinya sendiri untuk memberdayakan berpikir kritis melalui LACT. Degeng (2013:170) menjelaskan bahwa "Tersedianya media penting sekali untuk merangsang kegiatan belajar siswa. ... Interaksi antara siswa dengan media inilah yang sebenarnya wujud nyata dari tindak belajar. Hal belajar terjadi dalam diri siswa ketika mereka berinteraksi dengan media dan, karena itu, tanpa media, belajar tidak pernah terjadi”.

Predict: Aktivitas pada tahap ini diawali dengan mahasiswa membaca pernyataan pada aktivitas predict, dilanjutkan dengan menjawab beberapa pertanyaan terkait aktivitas predict. Pertanyaanpertanyaan pada aktivitas ini dimaksudkan untuk menggali kemampuan mahasiswa dalam memberdayakan berpikir kritis dengan menekankan pada indikator mampu memberikan penjelasan sederhana dan membangun keterampilan dasar sesuai materi yang dipelajari. Aktivitas memprediksi mempunyai makna mahasiswa dapat meramalkan (membuat suatu dugaan/hipotesis) pernyataan yang dipelajari dengan memberikan penjelasan kembali, sebagai bentuk daya kritis.

Beberapa model pembelajaran yang menekankan pada kemampuan berpikir seperti metode ilmiah dan model peraihan konsep yang dikembangkan Eggen dan Kauchak pada beberapa tahapan pembelajaran diawali dengan melakukan hipotesis atau memprediksi, Dalam model peraihan konsep, setelah siswa membuat kesimpulan, guru meminta mereka menjelaskan mengapa mereka meyakini setiap item yang ada merupakan atau bukan merupakan satu hipotesis yang sahih (valid). Proses mencurahkan pemikiran siswa ke dalam kata-kata adalah penting, baik bagi pemahaman mereka tentang konsep itu dan bagi latihan mereka berpikir kritis (Eggen dan Kauchak, 2012: 229). Pengembangan hipotesis dilakukan dengan memberikan contoh dan non contoh serta pertanyaan terbimbing seperti "Bagaimana jika...?" dan "Mengapa...?".

Organize: Aktivitas pada tahap ini meminta mahasiswa untuk dapat mengorganisasi kembali struktur-struktur yang sudah ada (struktur yang sudah dipelajari pada tahap predict). Pengorganisasian struktur-struktur tersebut dilakukan dengan terampil dalam membangun konsep ataupun pernyataan baik berupa pembuktian maupun aplikasi. Kecermatan dan keterampilan mahasiswa dalam mengorganisasi struktur-struktur menunjukkan bekerjanya daya kritis.

Mahasiswa dapat saja dikatakan telah terampil dalam membuktikan grup, namun terkadang masih kurang cermat dalam memperhatikan himpunan semestanya sehingga mengakibatkan pengambilan kesimpulan yang salah. Karenanya peneliti juga memberikan pertanyaan-pertanyaan pada LACT aktivitas organize yang dapat merangsang daya kritis mahasiswa.

Summarize: Aktivitas pada tahap summarize dilakukan dengan mahasiswa tetap belajar dan bekerja dengan LACT. Aktivitas ini dilakukan dalam diskusi kelompok. Kegiatan pada tahap ini menekankan kepada kemampuan mahasiswa dalam merangkum kemampuan yang telah diperoleh pada tahap-tahap sebelumnya. Kemampuan tersebut ditunjukkan dengan menyelesaikan permasalahan-permasalahan yang lebih kompleks. Penyelesaian diarahkan dalam strategi dan jawaban sebagai solusi dan kesimpulan. Strategi dan taktik yang disusun mahasiswa dituangkan dalam kotak peta konsep, sebagai bentuk rangkuman (summarize). Strategi dan taktik yang dituangkan dalam langkah nyata yaitu pada kotak jawab, merupakan bentuk daya kritis mahasiswa.

Tehnik concept map ini diilahami oleh teori belajar asimilasi kognitif David P Ausubel yang mengatakan bahwa belajar bermakna (meaningful learning) terjadi dengan mudah apabila konsepkonsep baru dimasukkan ke dalam kosenp-konsep yang lebih inklusif. Dengan kata lain, proses belajar terjadi bila siswa mampu mengasimilasikan pengetahuan yang ia miliki dengan pengetahuan yang baru (Munthe, 2009: 17). Munthe juga menambahkan bahwa guru dapat memanfaatkan concept map untuk aktivitas pembelajaran diantaranya "membuat rangkuman teks bacaan sebagai alternatif cara belajar.".

Evaluate: Aktivitas pada tahap ini diawali dengan mahasiswa menjawab beberapa pertanyaan terkait refleksi diri ketika belajar pada tahap sebelumnya (predict, organize, dan summarize). Peneliti juga mengarahkan pada pembahasan beberapa materi yang dianggap sulit dan mahasiswa banyak melakukan kesalahan. Refleksi sebagai bentuk evaluasi lebih banyak membantu peneliti dalam melakukan perbaikan pada pertemuan berikutnya agar hasil mahasiswa lebih maksimal. Pembahasan 
dari materi-materi yang dainggap sulit dan baru memberikan kepuasan bagi mahasiswa dengan mengetahui kebenaran.

Kata "memberdayakaan" mempunyai makna sebagai suatu usaha pengajar dalam mengelola situasi yang dapat mengaktifkan potensi mahasiswa dalam hal ini potensi berpikir kritis. Eggen dan Kauchak (2012: 114) mengungkapkan penekanan seorang guru dalam mendorong berpikir kritis di kelas mempunyai ciri: pertama, fakta bahwa guru menuntut siswanya memberikan bukti atas kesimpulan yang diambil. Kedua, kegiatannya menggambarkan kesalingtergantungan antara berpikir dan belajar. Ketiga, menekankan berpikir kritis dalam kegiatan belajar dengan memberikan pertanyaan-pertanyaan "Bagaimana kalian tahu?" dan "Mengapa...?". Dalam penelitian ini, memberdayakan berpikir kritis mahasiswa dilakukan dengan startegi pembelajaran POSE yang dituangkan dalam upaya nyata yaitu berupa lembar aktivitas critical thinking (LACT) dengan aktivitas predict, aktivitas organize, aktivitas summarize, dan aktivitas evaluate.

Penelitian Nurlaelah (tt:4) juga memanfaatkan lembar kerja mahasiswa (LKM) dengan media komputer program ISETL dengan metode pembelajaran ACE pada mata kuliah Struktur Aljabar I dan dipeoleh hasil cukup menunjang. LKM tersebut berisi konsep-konsep yang belum diajarkan di kelas. Tujuan mengerjakan lembar kerja tersebut untuk memberikan stimuli dan pengalaman yang mengarah pada konstruksi mental atas suatu konsep.

Disertasi Iswara (2010: 3) pada penelitian kuatitatif dengan startegi TSBRE yang merupakan terjemahan dari POSSE akronim dari predict, organize, search for structure, summarize, dan evaluate dengan menggunakan multimedia diantaranya lembar kerja. Hasil dari uji pengaruh yang dilakukan secara simultan selama satu semester menunjukkan bahwa terdapat pengaruh kemampuan membaca TSBRE dan kemampuan membaca dengan multimedia terhadap kemampuan membaca pemahaman. Dari hasil tes pada uji terbatas dan uji meluas dengan pengukuran regresi ganda pada tingkat signifikansi 5\%, disimpulkan bahwa terdapat pengaruh yang signifikan antara kemampuan membaca dengan kemampuan membaca pemahaman. Pembelajaran membaca secara simultan dengan strategi TSBRE dan multimedia memacu pembelajar untuk meningkatkan kemampuan membaca pemahaman. Walaupun demikian, temuan penelitian menyebutkan bahwa lembar kerja strategi TSBRE sangat memberatkan bagi pembelajar.

\section{PENUTUP}

Strategi pembelajaran POSE untuk memberdayakan critical thinking meliputi kegiatan orientasi dengan menginformasikan model pembelajaran, menyampaikan tujuan pembelajaran, pembentukan kelompok yang beranggotkan 3-4 orang, dan memberi lembar aktivitas critical thinking (LACT). Adapun kegiatan inti meliputi tahap predict dengan aktivitas membaca pernyataan untuk melakukan hipotesis yang dipandu dengan pertanyaan-pertanyaan dalam aktivitas predict pada LACT, dilanjutkan dengan Organize dengan aktivitas mahasiswa mengorganisasi dari struktur-struktur yang pernah diperoleh yang dipandu dalam LACT aktivitas organize, tahap berikutnya adalah Summarize dengan aktivitas memberikan masalah kepada mahasiswa untuk diselesaikan dan mengambil keputusan yang dipandu dalam LACT, dan tahap terakhir Evaluate merupakan refleksi dari kegiatan pembelajaran dengan mempresentasikan hasil dari aktivitas pembelajaran dan penguatan dari dosen.

Hasil penelitian berdasarkan tes akhir siklus, hasil observasi, dan LACT, dapat disimpulkan bahwa implementasi strategi POSE dapat memberdayakan berpikir mahasiswa prodi Pendidikan Matematika pada mata kuliah Struktur Aljabar I.

\section{DAFTAR RUJUKAN}

Degeng, Nyoman S. 2013. Ilmu Pembelajaran (Klasifikasi Variabel untuk Pengembangan Teori dan Penelitian). Bandung: Kalam Hidup.

Desmita. 2012. Psikologi Perkembangan Peserta Didik. Bandung: Penerbit: PT Remaja Rosdakarya Eggen, Paul; dan Kauchak, Don. 2012. Strategi dan Model Pembelajaran (Mengajarkan Konten dan Kemampuan Berpikir). Edisi Keenam. Jakarta: PT Indeks

Fisher, Alec. 2007. Berpikir Kritis Sebuah Pengantar. Jakarta: Penerbit Erlangga

Hitipeuw, Imanuel. 2009. Belajar dan Pembelajaran. Malang: Fakultas Ilmu Pendidikan Universitas Negeri Malang

Iswara, Prana Dwija. 2010. Ringkasan Disertasi: Penggunaan Strategi Tebak, Susun, Baca, Ringkas, Evaluasi (TSBRE) dan Multimedia bagi Peningkatan Kemampuan Membaca Pemahaman 
Mahasiswa Pendidikan Guru Sekolah Dasar UPI Kampus Sumedang. Online. http://file.upi.edu/Direktori/KD-SUMEDANG/197212262005011002-

PRANA_DWIJA_ISWARA/penelitian/pdf. Diakses 25 Nopember 2014.

Komalasari, Kokom. 2010. Pembelajaran Kontekstual: Konsep dan Aplikasi. Bandung: PT. Refika Aditama

Krulik, Stephen dan Rudnick, J. Milou, E. 2003. Teaching Mathematics in Middle School: A Practical Guide. Boston: Pearson Education Inc

Maha, Eka Rejeki dan Sibarani, Berlin. 2012. The Effect of Applying POSSE (Predict-OrganizeSearch-Strategi-Evaluate) on the Students' Reading Comprehension. (Online). http://jurnal.unimed.ac.id/2012/index.php/ellu/article/download/725/537. Diakses 9 Desember 2013.

Mercer, Cecil D dan Mercer, Ann R. 2005. Teaching Students with Learning Problems, seventh edition. New Jersey: Pearson Prentice Hall

Munthe, Bermawi. 2009. Desain Pembelajaran. Yogyakarta: Pustaka Insan Mandiri

Nurlaelah, Elah. tt. Lembar Kerja Mahasiswa sebagai Media Pembelajaran Mata Kuliah Aljabar I dengan Program ISETL. (Online). http://file.upi.edu/ MK-Elah_5/pdf. Diakses 21 Juni 2014

Sousa, David A. 2012. Bagaimana Otak Belajar. Edisi keempat. Jakarta: PT Indeks

Tim. 2007. Pembelajaran Inovatif dan Partisipatif. Jakarta: Dikti

Tzur, Ron dan Lambert, Matthew Allen. 2011. Intermediate Parcipatory Stages as Zone of Proximal Development Correlate in Constucting Counting-On: A Plausible Conceptual Source for Children's Transitory "Rgress" to Counting-All. Journal for Research in Mathematics Education, 2011, Vol 42, No5.

Untari, Sri dan Kamdi, Waras. 2007. Model-model Pembelajaran Inovatif. Malang: UM Press 